\title{
Din Eğitiminde Eleştirel Düşünme ve Öz Eleştiri*
}

\section{Critical Thinking and Self-Criticism in Religious Education}

Teceli Karasu ${ }^{\text {a, ** }}$

${ }^{a}$ Doç. Dr., Muş Alparslan Üniversitesi, İslami İlimler Fakültesi, Felsefe ve Din Bilimleri Bölümü, Din Eğitimi Anabilim Dalı, Muş/Türkiye. ORCID: 0000-0003-4218-2802

\section{MAKALE BİLGİSI}

Makale Geçmişi:

Başvuru tarihi: 30 Mart 2021

Düzeltme tarihi: 14 Mayıs 2021

Kabul tarihi: 21 Mayıs 2021

\section{Anahtar Kelimeler:}

Din Eğitimi

Eleştirel Düşünme

Öz Eleştiri

\section{A R T I CLE INFO}

\section{Article history:}

Received: 30 March 2021

Received in revised form: 14 May 2021

Accepted: 21 May 2021

Keywords:
Religious Education
Critical Thinking
Self Criticsm

\section{ÖZ}

Eleștirel düşünme, varlığı doğru anlamlandırmanın önemli bir unsurudur. Bu beceri, kișinin yaratılıș amacını idrak etmesine ve dolayısıyla dünya ahiret dengesini gözeterek yaşamasına katkı sağlar. Dahası eleștirel düşünme, kișinin bilgi, duygu ve eylemlerine yönelik doğru değerlendirme yapması anlamında, öz eleştirinin de zeminini oluşturur. Günümüz Müslümanlarının bu alanda yaşadıkları problemlerin çözümüne 1şık tutacak yeterli bilimsel çalışmanın olmayışı bu konunun ele alınmasının gerekçesini oluşturmuştur. Literatüre dayalı yapılan bu çalışmada eleştirel düşünme ve öz eleştiri ele alınmıştır. Çalışmada İslam'ın eleştirel düşünme ve öz eleştiriye yaklaşımı tahlil edildikten sonra, günümüz din eğitiminde bu becerilerin geliştirilmesinde kullanılabilecek yöntem ve teknikler tartışılmıştır.

\section{A B S T R AC T}

Critical thinking is an important element of correct interpretation of existence. This skill contributes to one's comprehension of the purpose of creation and therefore to live by observing the balance of the world in the hereafter. Moreover, critical thinking also forms the basis of self-criticism in the sense that a person makes correct evaluation of his / her knowledge, feelings and actions. Lack of sufficient scientific studies to shed light on the problems faced by today's Muslims has been the reason for addressing this issue. Critical thinking and self-criticism are discussed in this literaturebased study. In the study, after analyzing the critical thinking and self-criticism approach of Islam, the methods and techniques that can be used in developing these skills in today's religious education are discussed.

\section{Giriş}

Birey, soyut düşünmeye başladığı andan itibaren "hayat" üzerine tefekkür eder. Kim olduğu, nerede yaşadığg, kendi dışındaki varlıklar ile benzerlik ve farklılıkları gibi üzerinde düşündüğü kavramlar ile anlam arayışına cevap arar. Ancak çevresel şartlar, tembellik, ihmalkârlık, nefis ve şeytanın aldatmacaları gibi hem iç hem dış etkenler bireyin hakikat arayışını engelleyebilmektedir. Her dönemde aklın kullanmasını engelleyen amiller farklı olmakla birlikte, bunların ortaya çıkardığı sonuçlar benzerdir. Aklın kullanılmasını engelleyen bu etkenler, hakikati perdeleyerek kişinin ona ulaşmasının ve doğru bir hayat yaşamasının önüne set çekmektedir. Bu noktada eleştirel düşünme ve ona bağlı olarak geliştirilen öz eleştiri kişinin fitratına uygun olarak hakikati bulmasında yardımcı olabilecek önemli iki unsurdur.

Bireyin anlam çabasının muteber olduğuna ve bunun sürekli olacak şekilde sürdürülmesi gerektiğine yönelik en önemli destek vahiyden gelmektedir. Allah, gönderdiği son kitap Kur'an-1 Kerim ile insanın anlam arayışının değerli olduğunu vurgulamış dahası insan için bu çabanın bir gereklilik olduğunu vahyetmiştir. Kur'an-1 Kerim'e bakıldığında dünya ve ahiret mutluğunun ancak aklı doğru kullanma ile elde edilebileceğine dair pek çok ayet vardır.

* Bu çalışma, 7 Aralık 2020 tarihinde Muş Alparslan Üniversitesi İslami İlimler Fakültesinde düzenlenen İslam Düşüncesinde Eleştiri Kültürü ve Tahammül Ahlâkı II (Klasik Dönem- M. VII.- XII. Yüzyıllar) Sempozyumunda sunulan bildirinin geliştirilmiş halidir.

** Sorumlu yazar/Corresponding author. e-posta: t.karasu@alparslan.edu.tr 
$\mathrm{Bu}$ ayetlerin ortak vurgusu, kişinin kendini bilerek Rabbi ile doğru bir iletişim yolu geliştirmesinin zaruri olduğudur (Akto, 2019: 580). Kişinin kendini bilmesi, Rabbini ve Rabbinin yarattığ 1 diğer varlıkları anlamlandırması ise eş zaman içerisinde ve aklın sistematik olarak kullanılması ile mümkündür. $\mathrm{Bu}$ noktada Allah insanı bir başına bırakmamıştır. Gönderdiği kutsal kitaplar ile aklın nasıl kullanılması gerektiğine yönelik temel ilkeler vazetmiştir. $\mathrm{Bu}$ anlamda son ilahi kitap olan Kur'an'da aklın nasıl kullanılabileceğine dair ilkelerin yanında düşünmenin nasıl olması gerektiğine yönelik sayısız örnek de bulunmaktadır. $\mathrm{Bu}$ durum ilahi kitabın da eleştirel düşünmenin ve öz eleştirinin yapılmasını istediğini göstermektedir. "Yoldan çıkmışın biri size bir haber getirdiğinde doğruluğunu araştırın" (Hucurat, 49/6) şeklindeki uyarıyla, bilgiyi araştırma neticesinde sağlam delillere göre değerlendirme yapmayı salık vermektedir.

Kişinin eşyayı anlamlandırma çabası günümüzde farklı kavramlarla ifade edilebilmektedir. Yaratıc1, yansitıcı, analitik, metabilişsel düşünme gibi. Literatür incelendiğinde bu düşünme becerileri içerisinden hiçbir dönemde değerini yitirmeyen becerilerden biri eleştirel düşünmedir. Bu beceri, diğer düşünme becerileri gibi çevresel koşulların niceliğinden ve niteliğinden etkilenmektedir. Başka bir ifadeyle bu beceri, kalıtımın yanında çevresel etkenlere bağlı olarak gelişim gösterebilmektedir. Bu durum çevrenin, gelişimi kısıtlayan koşullardan ziyade gelişimi besleyen koşulları ortaya çıkarabilecek şekilde düzenlenmesini zorunlu kılmaktadır. Bu anlamda din eğitimi, insanları pasif alıcı olmaktan ziyade dayanaklı karar vericiler olarak yetiştirmek için çevre düzenlemesine dikkat etmelidir. Çünkü çevre koşullarının amaçlı ve planlı olarak düzenlenmesi, eleştirel düşünme ve öz eleştiri becerilerinin gelişiminde başat rol oynamaktadır.

Eleştirel düşünme, bireyin olaylara geniş bir perspektiften bakmasını hedefleyen, kendi duygu, düşünce ve davranışları üzerinde düşünüp kendisini sorgulayarak daha iyi anlamasına katkı sağlayan düşünme biçimidir. Bu düşünme biçiminde bilişsel hataların farkına varılmakta, tutarsız yargılar ayıklanmakta, konuya farklı boyutlardan bakılarak tahlil yapılabilmekte ve gerçekçi temellere bağlı olarak fikirler tahlil edilmektedir (Batar, 2019: 58). Kişi eleştirel düşünme sayesinde varoluşun nedenini kavramakta, sağlam bir ben tasavvuru geliştirmekte ve dünyayı daha doğru değerlendirerek yaşayabilmektedir. Buna karşın eleştirel düşünme becerisi gelişmemiş bireyler statik, dogmatik ve benmerkezci kalıplara hapsolmuş şekilde beşeriyetten insaniyete geçmekte sıkıntı yaşamaktadırlar.

Eleştirel düşünme, hem eleştiri hem de öz eleştiri yapabilmenin temel dayanağını oluşturmaktadır. Eleştiri kavramsal olarak daha çok, öteki kişinin, toplumun ve düşüncenin tahliline dayanırken öz eleştiri, kişinin kendi duygu, düşünce ve davranışlarını sorgulama süreci olarak ifade edilebilir. Bu anlamda öz eleştiri, içe dönük yapılan bir eleştiridir. Başka bir ifade ile kişinin kendisini objektif bir şekilde değerlendirmesi, hatalarına karşı ilkeli, açık ve dürüst bir tavır takınmasıdır. Nefsini temize çıkarmadan, kusurlarının üstünü örtmeden, onları başkalarına veya eşyanın tabiatına bağlamadan analiz edebilmesidir (Turşak, 2017: 130). Öz eleştiri, kişi, grup ya da toplumun kendi muhasebesini yapma, makul, tutarlı ve gerçekçi bir şekilde sorgulamadır. Birey ve toplumların gelişmesi açısından son derece önemli olan öz eleştiri, eksiklikleri araştırıp bulma, sslah ve ikmal etmek üzere daha iyisini yapma, yaptığı işin sağlamasını yapma, yeniden değerlendirme, gözden geçirme, kontrol mekanizması, tabiri caiz ise sigorta görevi görmektedir (Turşak, 2017: 130).

Literatür incelendiğinde eleştirel düşünme ve öz eleştiri ile ilgili pek çok bilimsel çalışmaya rastlamak mümkündür. Ancak din eğitiminde eleştirel düşünmenin ve öz eleştirinin ne anlama geldiği ve bunları geliştirmek için nasıl bir yöntemin takip edilebileceğini ortaya koyan bir araştırmaya rastlamadık. Bu çalışma, eleştirel düşünme ve öz eleştiri kavramlarını din eğitimi bilimi açısından tahlil etmeyi ve günümüz din eğitiminde bu becerilerin nasıl geliştirilebileceğine yönelik öneriler sunmayı hedeflemiştir. Alan yazına dayalı yapılacak çalışmada ayetlerin ne anlama geldiklerinin tespiti için Kur'an Yolu tefsirine müracaat edilmiştir. Kavramların asıl anlamları için ise Diyanet İslam Ansiklopedisi (DİA) temel kaynak kabul edilmiştir.

\section{Eleștirel Düşünme}

Eleştirel düşünmenin ne olduğunu anlamak için, bu terkibi oluşturan kavramların her birinin anlamlarına bakmak faydalı olacaktır. Eleştiri sözlükte; "bir insanı, bir eseri, bir konuyu doğru ve yanlış yanlarını bulup göstermek amacıyla inceleme işi, tenkit"1 olarak tanımlanmaktadır. Arapça tenkit anlamında kullanılan eleştiri, hataları ayıklayarak güzellikleri ortaya çıkarmak anlamındadır (Yıldız, 219: 387). Düşünmek, "bir sonuca varmak amaciyla bilgileri incelemek, karşılaştırmak ve aradaki ilgilerden yararlanarak düşünce üretmek, bilişsel yetiler oluşturmak, muhakeme etmek"2 demektir. Bu kavramlardan hareketle eleştirel düşünme ise doğru sonuca ulaşmak için malumatı dikkatlice inceleme, bütün boyutları ile tahlil etme, nesnel analiz yapma ve mantıklı değerlendirme yapabilme şeklinde tanımlanabilir (Mümtaz Ali, 2014: 158).

Günümüzde pek çok ilmi disiplin tarafından kullanılan eleştirel düşünmenin ilk insanla birlikte var olduğunu söylemek mümkündür. Her ne kadar günümüz disiplinlerince yüklenen anlamda olmasa da Hz. Âdem'in (as) öğrenebilme ve çıkarım yapabilme becerisiyle yaratılması (Bakara, 2/31), onun eleştirel düşünme becerisine sahip olduğunun dayanağı olarak kabul edilebilir. Pek tabi bu beceri çevresel etkenlere bağlı olarak geliştirilebilen bir beceridir. Nitekim bu becerinin geliştirilmesi noktasında tarihin kendisinden bahsettiği Sokrates, kendi ismi ile anılan bir yöntem geliştirmiştir. Bu durumu eleştirel düşünmenin Sokrates'le başladığ 1 şeklinde yorumlayanlar da olmuştur (Şahin, 2018: 41). Oysa Sokrates'in yaptığı, bu becerinin kullanılma yöntemini geliştirmek olmuştur. Bununla birlikte onun geliştirdiği Sokratik tartışma (buldurma) denilen bu teknik günümüzde eleştirel düşünme becerisi kazandırma tekniklerinden biri olarak kabul edilmektedir (İnan Kılıç, 2019: 426).

Eleştirel düşünmenin en çok kabul edilen tanımı, Amerikan Psikoloji Derneğinin (APA) öncülüğünde yapılan çalışmalar neticesinde geliştirilen tanımdır. $\mathrm{Bu}$ tanıma göre eleştirel düşünme, bireyin ne yapacağına ve neye inanacağına karar 
vermesi için çözümleyici, değerlendirmeye yönelik bilinçli yargilarda bulunması ve bu yargiları ifade etmesidir (Seferoğulu \% Akbıyık, 2006: 195). Buradan hareketle eleştirel düşünme; bir inancın, görüşün veya iddianın içeriğine, oluşma koşullarına ve sonuçlarına dikkat edilerek bilinçli bir araştırmanın sonucu oluşan düşünme biçimi olarak ifade edilebilir. Başka bir ifade ile bireyin bir gayeye bağlı olarak nasıl ve ne için düşündüğünün farkında olmasıdır (İnan Kılıç, 2019: 427).

Eleştirel düşünme becerisi gelişmiş bir kimsenin kanıtlanmış gerçekler ve öne sürülen iddialar arasındaki farklılığı yakalama, elde edilen bilgilere ait kaynakların güvenirliklerini test etme, kanıtlara bağlı olarak ilişkisiz bilgileri ayıklama, önyargı ve bilişsel hataları anlama, tutarsız yargiların tahlil etme, etkili soru sorma, kendi düşüncelerinin farkına varma gibi niteliklere sahip olması beklenir (Kökdemir, 2020).

Eleştirel düşünmenin temel yapıtaşları sorgulama ve açık görüşlülüktür. Sorgulama; doğru sorularla bir olay ya da olguyu etraflıca araştırmak ve elde edilen cevaplar üzerinde çıkarımda bulunabilmektir. Açık görüşlülük ise sorulması gereken soruları cesurca sormak, korkmamaktır. Bu anlamda eleştirel düşünme sistematik ve doğru bilgiyi elde etmek için takip edilen bir yöntem olarak ifade edilebilir (Arca, 2019: 251). Öte yandan eleştirel düşünmeyi katı akıcılık olarak ifade edilen rasyonalizmden de ayrı tutmak gerekir. Zira eleştirel düşünme rasyonalizm gibi duygusal deneyim ve tecrübeyi göz ardı etmez. Bilakis insanın herhangi bir konuda karar verirken ya da eyleme geçerken duygularının ne kadar etkili olduğunun farkında olarak hareket etmeyi gerektirir.

Eleştirel düşünme becerisi ile kazanılabilecek en önemli şey, insanın kendi düşünme tarzındaki benmerkezci yapıyı görebilmesidir (Nosich, 2018: 24). Bu anlamda eleştirel düşünme, kişinin kendisini ve aldığı kararları eleştirmesi anlamında öz eleştirinin temel belirleyicisidir.

\section{3. Öz Eleștiri}

Öz eleştiri, Türk Dil Kurumu sözlüğünde "Bir kişinin kendi davranışları üzerine yönelttiği yargı, otokritik" şeklinde tanımlanmaktadır. ${ }^{3}$ Kişinin daha doğru ve iyiye ulaşmak için kendi duygu, düşünce, tutum ve davranışları üzerinde düşünmesi öz eleştiri olarak ifade edilebilir. Öz eleştiri bir bakıma kişinin geçmişini anlamaya çalışarak gelecekte daha doğruya ve iyiye ulaşmak için uyguladığı düşünme biçimidir. Burada amaç daha iyiyi elde etmedir. Birey öz eleştiri sayesinde varsa yanlış ve eksikliğini görerek hareket eder. Şayet eylem ve düşüncesini doğru buluyorsa bunu yapmayı sürdürür.

Öz eleştiri, kişinin hakikate varmak amacıyla delillere dayalı olarak kendisini değerlendirmesidir. Ancak son yıllarda batıda yapılan araştırmalarda öz eleştiri kavramına olumuz bir anlam yüklenmektedir. Bu araştırmalarda, İngilizce self critism kavramının tercümesi olarak alınan öz eleştiri kavramının “öz suçlama” anlamında kullanıldığını söylemek mümkündür. Zira bu araştırmalarda öz eleştiri, depresyon yaşayan kişilerin özellikleri gibi sunulmaktadır. Dahası öz eleştiri yapanların sosyal çevreleri tarafindan onaylanma endişesi ya da reddedilme kaygısı taşıyanlar oldukları iddia edilmektedir. Ayrıca araştırmalarda öz eleştiri, başarısızlık duygularına kapılma, kendini değersiz görme, kendini suçlama gibi olumsuz tutum ve davranışlar ile ilişkilendirilmektedir. Kimi araştırmalarda ise stresli yaşam ile öz eleştiri kavramları arasında pozitif yönde anlamlı farkın olduğu dile getirilmektedir (Cox vd, 2007: 336-349).

Ülkemizde eğitim alanında yapılan kimi çalışmalarda da öz eleştiri kavramına batıda yüklenen anlama benzer anlamların yüklendiği söylenebilir. Örneğin, Doğan vd.'leri tarafindan öz eleştiri ile mutluluk arasındaki ilişkinin tespitini amaçlayan bir çalışmada, öz eleştiri kavramına olumsuz bir mananın yüklendiği görülmektedir. İyi olma, yaşam doyumu ve iyimserlik ile öz eleştiri arasında pozitif bir ilişkinin olmadığını iddia eden çalışmanın sonucu dikkat çekicidir. $\mathrm{Bu}$ çalışmanın sonucu öz eleştiri yapanların mutluluk seviyelerinin yapmayanlara nazaran daha düşük olduğudur. Böyle bir sonuca varılma nedeni, öz eleştirinin bireyin kendisiyle ilgili olumsuz düşünce ve inançları olarak değerlendirilmesi olduğu söylenebilir (Doğan vd, 2013: 391 400).

Yukarıda yer alan iddiaların zayıf olduklarına yönelik en ciddi bulgular yine eğitim alanında yapılan çalışmalar tarafından ortaya konmaktadır. Örneğin eğitimde yapılan bazı çalışmalarda öğrencilere üst düzey zihinsel beceriler ile öz eleştiri arasında pozitif yönlü anlamlı ilişkiler mevcuttur. Çünkü bu düşünmelerde bireyin öğrenmesini yapılandırması, yaptığı eylemi sorgulaması ve olaylardan ders çıkarması beklenmektedir (Eğmir, 2019: 208). Dahası yine eğitimde öğrenciye kazandırılması gereken temel beceriler arasında yer alan eleştirel düşünme, öz eleştirinin kuramsal alt yapısını teşkil eder. Burada bireyin bir olayı bütün yönleri ile analiz edebilmesi söz konusudur. Bu durumda birey doğal olarak benmerkezcilikten ve taassuptan uzaklaşır (Paul ve Elder, 2000). İçerisinde şüphecilik, kanıt, varsayım, sebep sonuç olan öz eleştiri aklın işlevselleşmesine de katkı sağlar. (Karasu, 2019: 446). Daha da önemlisi öz eleştiri, bireyi eylemlerin bilinçli bir uygulayıcısı seviyesine yükseltir ve "hoşgörü" erdemini edinmesini sağlar. Nitekim öz eleştiri kavramını öz değerlendirilme anlamında kullanan çalışmalarda öz eleştirinin kişinin empati yapmasına katkı sağladığ 1 (Aktaş, 2020: 62), başarısını olumlu etkilediği, mutluluğunu arttırdığı, potansiyelinin farkına sonucu ortaya koymaktadır (Çorapçıgil, 2014: 72). Kimi çalışmalar ise batıda öz eleştiriyi olumsuz değerlendiren araştırmaların Türk öğrenciler için geçerli olmadığını ortaya koymuşlardır. Bu çalışmalarda Türk öğrencilerin öz-anlayış ile pozitif duygu ve yaşam doyumu arasındaki ilişkinin pozitif, öz-anlayış ile negatif duygu arasındaki ilişkinin ise negatif yönde anlamlı olduğu bulunmuştur (Deniz vd., 2012: 438). Kavrama yüklenen anlamın farklı olmasının farklı sonuçların ortaya çıkmasına neden olduğu söylenebilir.

Eleştiride olduğu gibi öz eleştiride de takip edilmesi gereken üslup önemlidir. "Sen Rabbinin yoluna hikmet ve güzel öğütle çağır ve onlar ile en güzel şekilde mücadele et." (Nahl, 16/125) ayeti bir anlamda kişinin kendi tutum ve davranışlarını da değerlendirirken takip etmesi gereken metot hakkında bilgi verir. Eleştirel düşünmenin, eleştirinin (Gülaçar, 2019: 504) ve öz eleştirinin temel parametresi Allah rızasını elde etme olmalıdır. Zira yapılan bir hata ya da 
yanlışı sürekli akılda tutmak, bundan dolayı kendini harap edip suçlamak, kendini başkaları ile kıyaslayarak alçak görmek dinin tasvip ettiği öz eleştiri değildir. Dahası kendi elinde olmayan, cüz'i iradesini aşan konularda hayıflanma kişin öz saygısını yitirmesine neden olabilir. Bu durum ise yarardan çok kişiye zarar verir.

Öz eleştiriyi kişinin kendisi ile ilgili olumsuz söylemleri olarak değerlendiren çalışmalara bakıldığında bunların daha çok batıda geliştirilen ölçeklerin Türkçeye uyarlaması ile elde edilen ölçme araçlarına dayalı yapıldığı görülmektedir. Oysa öz eleştiri, kişinin sahip olduğu dünya görüşüyle de bağlantılıdır. Yaşam felsefesini Kur'an ve Sünnet'ten alan bir Müslüman için öz eleştiri gerekli ve muteberdir. "Kendinizi beğenip temize çıkarmayın." (Necm, 53/32). ayeti bu minvalde değerlendirilir. Çünkü İslam'ın izlerinin olduğu bir kültürde öz eleştiri bir anlamda "oto kontrol" anlamındadır. Benzer şekilde öz eleştiri kavramı tevazu ve hoşgörü kavramları ile irtibatlıdır. Zira öz eleştiriyle kendi hatalarının farkında olan birey başkalarının hatalarına yaklaşım noktasında daha makul ve hoşgörülü olur (Demir, 2010: 101).

\section{Din Eğitiminde Eleştirel Düşünme ve Öz Eleștiri}

Eleştirel düşünme ve öz eleştiri bireyin hayatının pek çok noktasında kullanabileceği becerilerdir. $\mathrm{Bu}$ becerilerle, dünya işlerinin üstesinden daha kolay gelinebileceği gibi, kutsala yakınlaşma da sağlanabilir. Kur'an'ın pek çok yerinde vurgulanan aklın kullanılması vurgusu, bu becerilerin edinilmesini zorunlu kılmaktadır. Aynı şekilde insana verilen "iç ve dış uyarıları işleme, anlamlandırma ve bunlardan yeni bilgiler edinme" sorumluluğu da eleştirel düşünme becerisiyle mümkün hale gelebilir. İç ve dış uyaranları ayet kavramı ile formüle eden Kur'an'a (Batar, 2019: 58) göre bu ayetlerden gerekli uyarı almayanlar hayvanlardan daha aşağı bir kategoride yer almaktadır.

"Andolsun biz, cinlerden ve insanlardan birçoğunu cehennem için yaratmış olduk. Bunların kalpleri vardır ama onlarla kavrayamazlar; gözleri vardır ama onlarla göremezler; kulakları vardır ama onlarla işitemezler. Onlar hayvanlar gibidir, hatta daha da şaşkındırlar. İşte asıl gafiller onlardır." (Araf, 7/179).

Yukarıda yer alan ayette de görüldüğü üzere Kur'an, insanın sahip olduğu potansiyeli kullanmasını istemektedir. Öğrenme potansiyeline sahip insan, aktif bir alıcı olarak kevni ve kitabi ayetlerden faydalandıkça değerini muhafaza edebilir.

Eleştirel düşünebilme ve öz eleştiri yapabilme becerileri, düşünmenin en önemli unsuru olan aklı kullanmakla mümkündür. Çünkü akıl sayesinde muhakeme yapılabilir, istidlalde bulunulabilir ve güzel çirkinden ayrılabilir. Bu anlamda Kur'an'da akla önemli bir yer ayrılmakta ve muhataptan aklını kullanması istenmektedir. Kur'an'da düşünme becerileriyle alakalı 700'ü aşkın kullanımla birlikte 49 yerde aklın fiil formunda kullanılması, dinamik uygulama alanına hitap etmesiyle açıklanabilir. Başka bir ifadeyle Kur'an'da yer alan akıl, bir nesneye verilen isim olmaktan ziyade görev/vazife anlamındadır. Böylece insanın akıl vasıtasıyla düşünmesi, üretmesi, deney ve tecrübeyle bilgi sahibi olması ve böylece hakikati bulması teşvik edilmektedir (Karasu, 2020: 21).
Eleştirel düşünme ve öz eleştirinin sadece kişiler için değil toplumlar için de önemli bir muhasebe yöntemi olduğu söylenebilir. Kur'an'dan hareketle hem birey hem de toplum için hakikate ulaşmanın yollarından birinin eleştirel düşünme becerisini kazanma ve öz eleştiri yapabilme olduğu belirtilebilir. $\mathrm{Bu}$ anlamda $\mathrm{Hz}$. Adem ve eşinin yasağ çiğnediklerini anladıklarında; Ey Rabbimiz! Biz kendimize yazık ettik, yaratılış gayemize aykırı hareket ettik; bizi bağışlamaz, bize merhamet etmezsen büyük zarara uğrayanlardan olacağız (A'raf, 7/23) demeleri bunun en önemli göstergelerindendir. Hatalara karşı açık, ilkeli ve dürüst olanlar, nefislerini temize çıkarmadan hatalarıyla cesurca yüzleşebilirler. Allah'ın Hz. Yusuf'un kıssası aracılığı ile insanlardan istediği açıktır. "Yine de ben nefsimi temize çıkarmıyorum. Çünkü nefis, Rabbimin acıyıp koruması dışında, daima kötülüğü emreder; şüphesiz Rabbim çok bağışlayan, pek esirgeyendir." Ayette görüldüğü gibi kişinin kendisiyle gerçek manada yüzleşebilmesi, öz eleştiriyi zorunlu kılmaktadır. Dahası Allah'ın Hz. Peygamberi uyarması neticesinde o da öz eleştiri ile yaptığı uygulamaları tekrar değerlendirmiştir (Elmas, 2019: 159). Bir anlamda iç muhasebe olan öz eleştiri, kişinin düşünme tarzındaki benmerkezci yapıyı görerek, bunu düzenleyebilmesidir. Nefsini sorgulayarak yaratış amacına ters uygulamaları fark etmesi, pişmanlık duyup bundan dönmesidir. Bir mü'minin kendi zaaflarının, kusurlarının farkına varması tövbe ve istiğfarla Rabbine sığınmasını beraberinde getirir. Böylece mümin, Rabbinin koyduğu ilkeleri dikkate alarak şahsiyetini sslah ve ikmal edebilir (Turşak, 2017: 13).

İslam'da önemli bir yer tutan "tövbe" kavramını da öz eleştiriden bağımsız değerlendirmek zordur. Ruhun Allah’a açılışını ve yücelişini hedefleyen tövbe, "dinde yerilmiş şeyleri terk edip övgüye lâyık olanlara yönelme" (Topaloğlu 2020) biçiminde tanımlanır. Dinde yerilenin kişinin bu dünya ve ahreti için zararlı olan şeyler olduğu dikkate alındığında bir anlamda dinin, kişiden öz eleştiri yaparak yanlışlardan dönmesini istediği söylenebilir. Zira Allah pek çok ayette akılların kullanılarak yanlıştan dönülmesi gerektiği uyarısında bulunmaktadır (Hud, 11/3; Tahrîm, 66/8; Karasu, 2019).

Öz eleştiri, kişisel analiz ve onarım olarak da değerlendirilebilir. Örneğin kibrinden dolayı hatalarını kabul etmeyen kişi bir müddet sonra kendisini kusursuz görebilir. Oysa hata işlemek insan hayatının bir gerçeğidir. Hatalardan ders çıkarılması ise ancak öz eleştiri ile mümkündür. "...nefsini arındıran kurtuluşa ermiştir." (Şems, 91/9) ayetiyle Allah bir anlamda otokontrol olarak öz eleştiriye teşvik etmektedir.

Öz eleştiri doğru benlik algısının edinilmesinde de başat rol oynamaktadır. Kişinin hali hazırdaki benlik algısı ile ideal benlik algısını birbirine yakınlaştırması ancak öz eleştiri ile mümkün hale gelir. Zira kişi, bulunduğu yer ile varmak istediği yer arasındaki mesafeyi bu şekilde kapatabilir. Böylece kişi, bencil eğilimlerinden ve enaniyet duygusundan kurtulmanın yolu olarak kendisine ben kimim? Hayatta yaşam hedefim nedir? Doğru yaşam için neler yapabilirim? gibi sorulara Kur'an merkezli çözüm bulabilir (Turşak, 2017: 132).

Kişinin öz eleştiri yaparken Kur'an ve Sünnet merkezli değer ölçütlerini belirlemesi önemlidir. Aksi takdirde kişi öz 
eleştiriden saparak, öz suçlamaya yönelebilir. Bu durumda kişi, fitratından ve kendi gerçekliğinden uzaklaşır. Ümitsizlik, suçluluk, güvensizlik ve mutsuzluk insanın en yoğun yaşadığı duygular haline gelir. Dolayısıyla kişinin kendisini objektif dini ilke ve değerlere göre değerlendirmesi gerekir. Bu anlamda Hz. Peygamber özelinde Allah'ın öz eleştirinin usulünü göstermesi dikkate değerdir. Hz. Peygamber insanların şirk bataklığından çıkmada direndiklerini görmüştür ve bu durum onu ruhen daraltmıştır. $\mathrm{Bu}$ durumdan bir anlamda kendisini sorumlu tutmasi neticesinde; "İman etmiyorlar diye neredeyse kendini helâk edeceksin!" (Şuarâ, 26/3). "Sen ancak bir uyarıcısın" (Gâşiye, 88/21) şeklinde uyarıyla karşılaşmıştır. Burada gözden kaçmaması gereken husus, öz eleştirinin de bir usule ve İslami ilkelere göre yapılmasının gerekliliği ve bir öz suçlamaya dönüşmemesidir.

\section{Din Eğitiminde Eleştirel Düşünme ve Öz Eleştiri Becerisi Kazandırma}

Eleştirel düşünme ve öz eleştiri becerilerinin geliştirilmesi noktasında ortak bir anlayıştan söz etmek mümkün değildir. Bununla birlikte örgün eğitim ortamında iki yaklaşımdan söz edilebilir. Birincisi ayrı özel bir ders aracılığı ile ikincisi müfredatta yer alan diğer derslerde yapılabilecek düzenlemelerle bu becerilerin öğrencilere kazandırılmasıdır. Ülkemizde her iki yöntemle öğrencilerin "öğrenmeyi öğrenme" noktasında yetiştirilmesine yönelik çabalar mevcuttur. İlk anlayışın örneği olarak Milli Eğitim Bakanlığı (MEB) tarafından seçmeli olarak programa yerleştirilen "düşünme eğitimi" adlı dersi ifade etmek mümkündür. İkinci anlayış ise Din derslerinin de yer aldığı müfredatta yer alan diğer dersler aracılığı ile ögrencilerin düşünme becerilerinin geliştirilmesinin gerektiğine yönelik görüştür.

Din dersi aracılığı ile öğrencilerin eleştirel düşünme ve öz eleştiri becerilerinin geliştirilmesi, onların akıl ile vahiy ilişkisini doğru kurabilmelerine katkı sağlar. İnanç, ibadet, ahlak konularında mantıklı ve tutarlı bir felsefeye sahip olarak hayatlarını ikame etmelerine yardımcı olur. Bu beceriler, öğrencileri küreselleşen dünyamızda farklı din mensuplarını anlama noktasında bilişsel olarak yetkinleştirir. Onları metni tartışmaksızın kabul etmekten (Bilgin, 2019: 49), mezhep, tarikat, cemaat taassubundan ve bilinçsiz taklitlerden uzaklaştırır.

Öğrencilerin eleştirel düşünme ve öz eleştiri becerilerini geliştirmede en önemli husus, akla işlevsellik kazandıran strateji, yöntem ve teknikleri kullanabilen öğretmenin varlığıdır. Ayrıca eleştirel düşünme becerisinin öğrencilere kazandırılması konusunda, öğretmenin resmi sorumluluğu bulunmaktadır. Öğretim programında yer alan; "Eleştirel düşünme, problem çözme ve performanslarına ait gelişmelerini özendirmek için çeşitli öğretim stratejileri uygular." (Öğretmen Yetiştirme ve Eğitimi Genel Müdürlüğü, 2002) ifadesi, eleştirel düşünme becerisi geliştirmesi hususunda, Din dersi öğretmenlerini görevli k1lmaktadır (Aydın, 2019: 417). Ancak Din dersleri öğretmenlerini yetiştiren İslami ilimler ve İlahiyat fakültelerinde eleştirel düşünme adlı bir ders bulunmamaktadır. Mantık ve Kelam derslerinin de bu noktada yeterli olduğunu söylemek zordur. Dolayısıyla öğrencilerin eleştirel düşünme becerisini geliştirecek din dersi öğretmenlerini destekleyen bir kurum da yoktur. $\mathrm{Bu}$ durum, zamanla derslerin sorgulamaya açık olmayan, dogmatik bilgilerin verildiği dersler hüviyetini almalarına sebep olabilmektedir (Kılıç, 2019: 435-436)

Toplum bir bütündür ve onun değişimi için kültürel atmosferin değişimi önemlidir. Dolayısıyla eleştirel düşünme ve öz eleştiriyi destekleyecek diş çevre ve okul/sınıf ortamının hazırlanması gerekir. Düşünmeksizin itaati benimseyen bir kültürde öğrencilerin eleştirel düşünme ve buna bağlı olarak öz eleştiri becerisi kazanmaları oldukça zordur. Bu durum, öğretmenin sınıf ortamında kullanacağı yaklaşıma ek olarak öğrencinin aile ve diğer dış çevrenin de öğrencilerin akıllarını kullanmalarına, öğrenmelerinin sorumluluğunu almalarına yardımcı olmalarını zorunlu kilmaktadır.

Dil ve düşünme arasında bir bağ bulunmaktadır. Dil için düşünmeye, düşünmek için dile ihtiyaç vardır. Eleştirel düşünmenin gerçekleşmesi için öncelikle din dilinin geliştirilmesine ihtiyaç duyulmaktadır. Dine ait kavramlarla düşünme gerçekleşeceğinden öğrencilerin hem niteliksel hem de niceliksel olarak yeterli kavrama sahip olması önemlidir. Örneğin sadece 32 farzı ezberletmek, kalıcı ve anlamlı bir öğrenmeye katkı sağlayamaz. Bundan dolayı öğrencinin kullandığı kavramı bilmesi, anlamlandırması gerekir. Dil ile ilgili diğer önemli bir husus ise dilin kullanımıdır. Toplumda alimlerin, imamların ve Din dersi öğretmenlerinin arasında yaygın olan olumsuz bir dil kullanım alışkanlığı vardır. Din ile ilgili konuyu anlatan kişilerin Kur'an ve Sünnetten çıkardığg anlamı, "Kur'an böyle buyuruyor", "Allah böyle emrediyor." şeklinde kullanmaları, muhatabın düşünmesine izin vermediğinden eleştirel düşünme ve öz eleştiri becerilerinin gelişmesine engel olduğu söylenebilir. Oysa ilk dönem Müslümanlar, dini metinler ile ilgili yorum geliştiren âlimler, sözlerinin sonunda "Doğrusunu en iyi Allah bilir" demekteydiler (Ercüment, 2019: 510). Öğrenmenin gerçekleştiği sınıfin kültürel ortamı da eleştirel düşünme ve öz eleştirinin gelişmesinde etkilidir. Özgür bir öğrenme ortamında, düşüncesini ifade ettiği için yerilmeyeceğini, alaya alınmayacağını bilen bir öğrenci kendi öğrenmesini daha kolay yapılandırır. Öğrenci aktif olarak öğrenme süreci üzerinde düşünerek, öğrenme stilini belirleyebilir. Konunun mahiyetine bağlı olarak öğrenme stratejileri geliştirebilir, sabır erdemi de öğrenilebilir (Koca, 2019: 131). Dolayısıyla bu öğrenme ortamında eleştirel düşünme ve öz eleştiri kültürü gelişebilir. $\mathrm{Bu}$ anlamda okullar, öğrencilerin kendilerini özgürce ifade ettikleri, düşüncelerini yönetebildikleri, öz eleştiri becerisi kazanabildikleri yerler olmalidır (Ev, 2014: 426).

Öğretmenin sınıf ortamında kullandığı öğretim yöntem ve teknikleri, eleştirel düşünme ve öz eleştiri becerilerinin gelişmesine katkı sağlamaktadır. $\mathrm{Bu}$ anlamda Din dersi öğretmenlerinin kullanabileceği bazı yöntem ve teknikler vardır. $\mathrm{Bu}$ tekniklerin ortak özellikleri; öğretim sürecinde öğrencilerin aktif olmalarını, bir olay ya da olguya farklı birkaç açıdan bakabilmelerini ve grup çalışmalarını desteklemeleridir. Ayrıca öğretmenin eleştirel okuma, aktif dinleme, serbest tartışma (Şahin, 2018: 41), doğru soru sorma, analitik yazarlık, karşılaştırmalı analiz, $5 \mathrm{~N} 1 \mathrm{~K}$ ve dinamik değerlendirme gibi aktivitelerle öğrencilerin bu becerileri kazanmalarına yardımcı olması gerekir. 
Biz burada önemli gördüğümüz birkaç yönteme yer vermek istiyoruz.

\section{Altı Şapkalı Düşünme Tekniği/Altı Uygulama} Ayakkabısı: Altı şapkalı düşünme tekniği yeni fikirler üretmeyi, düşünceleri ve önerileri belli düzende sunmayı ve sistemleştirmeyi sağlamaya katkı sağlayan bir tekniktir. Çok yönlü, eleştirel, analitik ve yaratıcı düşünmeyi sağlayan bu teknik; uygulama, analiz, sentez ve değerlendirme basamaklarındaki hedef davranışların kazanılmasında kullanılabilir. Farklı renklerdeki şapkaların kullanıldığı bu teknikte, her şapka amacı ve bakış açısını temsil eder. Bu teknikte öğrencilere farklı renklerde şapkalar verilebileceği gibi, bir öğrenciye farklı şapkalar da verilebilir. Beyaz şapka ilgili soruna/olaya tarafsız, net bilgilerle ve nesnel olarak yaklaşmayı; kırmızı şapka duygusal, içgüdülere ve sezgilere dayalı bakmayı; siyah şapka şüpheci, zayıf, risk ve kötümserlik üzerinden değerlendirmeyi; sarı şapka iyimser, olumlu, avantaj ve getirilere yoğunlaşmayı; yeşil şapka farklı düşünmeyi, yaratıcılığı ve alternatif çözümler üretmeyi; mavi şapka farklı görüş ve önerileri sentezleyip sistemleştirip bir bakıma sonuç çıkarmayı temsil eder. Din eğitiminde problem çözme etkinliği olarak altı şapkalı düşünme tekniğinden yararlanmak mümkündür (Şenşekerci \&Bilgin, 2008: 34-35; Kılıç, 2019: 438-439).

Altı Ayakkabı Uygulama tekniğinde; ise uygulamayı çağrıştırdığı için sembol olarak ayakkabılar kullanılmış ve teknik sembollere bağlı olarak altı ayakkabı uygulama tekniği şeklinde anılmaktadır. Farklı durumlar için farklı ayakkabı sembolleriyle uygulama yapılmaktadır. Lacivert resmi ayakkabı; rutin işleri ve resmi prosedürleri; gri spor ayakkabısı araştırma yapmayı, bilgi toplamayı ve delilleri kullanmayı; kahverengi yürüyüş ayakkabısı uygulamada inisiyatiflerden ve esneklikten faydalanarak sonuca ulaşmayı; turuncu lastik çizmeler acil müdahaleyi ve güvenliğin sağlanmasını; pembe ev terliği insanların duygu ve düşüncelerine karşı hassas olmayı; mor binici çizmesi ise uygulamada bir yetkinin sağladığı üstünlüğü kullanmayı temsil eder. Edward De Bono tarafindan sistematize edilen altı şapkalı düşünme ve altı ayakkabı uygulama teknikleri bireylerin farklı açılardan bir olay/durumu değerlendirerek doğru olanı ya da doğruya yakın olan anlamı elde etmeyi amaçlar. Din eğitiminde bu yöntemler, öğrencilere dinî bir olayı farklı boyutlarıyla değerlendirme becerisi kazandırma imkânı sağladığından önemlidir. Ayrıca istişare, şura gibi pek çok İslami anlayışın kazanılmasına katkı sağlar.

Beyin Fırtınası: Beyin fırtınası, gerçek ya da kurmaca problemlere yönelik çözüm önerileri geliştirmek veya bir konuyu netleştirmek amacıyla kısa sürede uygulanan grup tartışma tekniğidir. İki etaptan oluşmaktadır. İlk etapta sorunla ilgili bütün öğrencilerin katılımıyla kısa sürede çokça fikir üretilir. Söylenenlerin kalitesinden çok; sayıları ve olağan dışı olmaları önemlidir. İkinci etapta, üretilen fikirlerin eleştirel bakış açısıyla tasnifi yapılarak nitelikli çözümlere ulaşılır. Bu tekniğin sağlıklı uygulanabilmesi için öncelikle öğrencilerin kendi fikirlerini özgürce ifade edebilecekleri bir sınıf atmosferinin yaratılması gerekir. Bu teknikte, reddedilme, küçük düşme kaygıları yerine öz güven ve cesaret duyguları kazanan öğrenciler bir taraftan grup içerisinde kendilerini ifade ederken öte yandan da yaratıcı, özgün, farklı, çılgın fikirler geliştirebilirler (Paul ve Elder, 2020; Şenşekerci \& Bilgin, 2008: 34-35; Kılıç, 2019: 438439).
Beyin fırtınası tekniğinde sorular, istenenin aksi şekline dönüştürülerek de uygulanabilir. Literatürde ters beyin firtınası olarak isimlendirilen bu tip sorularla öğrencilerin düşünme melekeleri harekete geçirilebilir. Örneğin "Büyüklere saygının, küçüklere sevginin olmadığı bir dünya için neler yapılmalıdır? sorusu ile öğrencilerin konu üzerinde düşünmeleri sağlanabilir.

Hz. Ömer henüz çocukken İbn-i Abbas'1 meclise dâhil etmiş ve ayetlerin kastettiği mananın anlaşılmasında yetişkinler gibi onun da görüşlerine başvurmuştur. Hz. Ömer, "Yeğenim görüşlerini söyle, kendini küçük görme" diyerek fikirlerini beyan etmede onu teşvik etmiştir. Bu örnekteki gibi öğretmenin her öğrenciye kendi düşüncelerini ifade etme ortamı sağlaması söz konusu becerilerin gelişmesine katkı sağlar.

Empati/ Tarihsel Empati: Empati, bireyin kendisini karşısındakinin yerine koyarak o bireyin duygu ve düşüncelerini hissetmesi, onu anlamaya çalışması ve ona iletmesi sürecidir. Tarihsel empati ise bugünün değer yargılarından ve bakış açısından uzaklaşarak dönemin şartlarına uygun olarak geçmişte yaşayan insanların amaç, düşünce ve duygularını onların gözüyle anlama ve açılama becerisidir. Çeşitli bilişsel beceriler ve eldeki kanıtları kullanarak empati yapabilen kişi, kendi zihinsel kapasitesini arttırma yoluna girmiş olur. Başka bir deyişle kişi ne kadar farklı ve iyi empati yapabiliyorsa üst düzey zihinsel becerilerini o derece iyi kullanıyor demektir. Eğitimde daha çok soyut işlem döneminde uygulanan bu yöntem, birlikte yaşamaya da ciddi katkı sağlar. Empati yöntemiyle kişi, olayları farklı açılardan değerlendirme ve daha sağlam karar verme becerisi kazanır. Böylece eleştirel düşünme ve öz eleştiri yapma becerilerini kazanır. Hz. Peygamber tebliğ görevini yerine getirme sürecinde empati yönteminden çokça yararlanmıştır. Örneğin zina yapmak istediğini belirten gence, buldurma yoluyla empati yaptırmış ve gence bu fikrin yanlış olduğunu buldurmuştur. Hz. Peygamber farklı kimselerin perspektifinden olayın nasıl göründüğünü göstermeye çalışmıştır.

Keşfederek öğrenme (Buldurma): Buldurma yöntemi, öğrencilerin belli bir konudaki mevcut bilgilerinden hareketle yeni bilgilere ulaşmasını sağlayan bir yöntemdir. Buluş stratejisine dayanan yöntemde öğrencilerin tümevarım yoluyla ilkelere ve genellemelere ulaşması beklenir. Öğretmenden beklenen, mantıklı sorularla öğrencilerin yeni bilgiler edinmelerine aracılık etmektir. Bunun için öğretmenin, öğrencilerin hazırbulunuşluklarını ve ön öğrenmelerini dikkate alarak öğretim sürecini yapılandırması gerekir. Buldurma yöntemi düşünme yeteneğini geliştirmede önemli katkı sağlayabilecek bir yöntemdir.

Buldurma yöntemi çok farklı şekillerde uygulanabilir. Bunlardan en dikkat çekeni sokratik tartışma tekniğidir. Bu teknik, alaysı ve doğurtmaca aşamalarından oluşur. Alaysı aşamasında öğrencilerin doğru bildikleri yanlışların tespit edilmesi, doğurtmaca aşamasında ise ipuculu sorularla öğrencilerin yeni bilgiyi edinmeleri sağlanır. Sokrat semineri olarak bilinen teknik ise daha çok yazılı metinlerin anlaşılmasında uygulanır. Öğrencilerin metindeki düşünceleri bulmaları ve tahlil etmelerine dayanır. Sokrat seminerinde çember şeklinde oturan öğrenciler tartışarak metni birlikte anlamaya çalışırlar. Öğretmen rehberliğinde 
öğrencinin bilgiye ulaşması ve bilgiyi yapılandırması, öğrenciyi aktif kıldığından onun üst düzey zihinsel becerilerini kullanmasına katkı sağlar. Okunan parçanın kaynağı, gerekçesi delilleri, etkileri ve sonuçları tahlil edilir (Şahin, 2018: 42). Bu yöntemlerle işlenen ders, öğrencinin daha sonra karşılaştı̆̆ı olayları daha eleştirel değerlendirmesi ve kimi zaman öz eleştiri yapmasına katkı sağlar.

Cibril hadisi olarak bilinen hadiste melek Cebrail ve Hz. Peygamber arasında geçen diyalog buldurma yönteminin örneği olarak zikredilebilir. ${ }^{4}$ Bu diyalog, Resulullah'ın aktif buldurma yöntemi ile tebliğ vazifesini yaptığının göstergesidir. $\mathrm{O}$, kişinin bilgilerinden hareketle doğruya ulaşması noktasında rehberlik etmiştir. Böylece kişi, eleştirel düşünme becerilerinden faydalanmış, daha sonra öz eleştiriyle hatasını kavramış ve nihai olarak bu süreci tövbe ile sonuçlandırmıştır.

Rol yapma: Öğrencilerin kendi duygu ve düşüncelerini bir başkasının kimliğine bürünüp o kişi gibi davranarak ifade ettikleri yaşantıya dayalı anlatım tekniğidir. Bu tekniğin temel amacı, başkalarının düşündüklerini, hissettiklerini ve davranışlarını anlamaya çalışmaktır. Başkalarının farklı durumlarda nasıl tepkide bulunacağını anlamak, bir olayın farklı açılardan nasıl göründüğünü anlamaya yardımcı olur. İşbirliğini gerektiren bu teknik, gerçek dünyada da insanların birlikte yaşamasına ciddi katkı sağlar. Teknikle öğrenciler duygularını tanırlar ve düşüncelerinin bilincine varırlar. Bir bakıma öz eleştiri yapma firsatı elde ederler. Bunlara ek olarak bu yöntem, sorunla baş etme, problem çözme, olaylara farklı açılardan bakma, empati yapma, toplumsal olayları derinlemesine kavrama gibi noktalarda öğrencilere katkı sağlayan bir tekniktir. Drama (yaratıcı drama) ise tiyatral ve doğaçlama tekniklerinden yararlanılarak bir olay, fikir, durum veya yaşantının oyunsu süreçlerle canlandırılmasıdır. Öğrencilerin hayal dünyalarını ve yaratıcılıklarını kullanmalarına imkân sağlayan bu teknik, rol yapmadan farklı olarak sabit bir metne dayalı olmaktan ziyade doğaçlamaya dayalıdır. Başka bir deyişle rol oynamada roller önceden dağıtılıp öğrencilerin o rollere bürünmeleri için zaman verilirken, dramada öğrenci verilen rolü istediği şekilde canlandırabilmektedir. Rol oynama ve drama teknikleri öğrencileri akıllarını kullanmaya, başkalarını anlamaya, böylece birlikte yaşama becerisi geliştirmeye sevk eder. Bu teknikte öğrenciler öğrenmeyi, eğlenme ve deneyimlemeyle gerçekleştirdiklerinden öğrenme kalıcı olur.

Entelektüel Normlar Etkinliği: Entelektüel normlar, bir kimsenin herhangi bir konu hakkında düşünürken, düşüncesini geliştirmek için dikkate aldığı normlardır. Bunlar; açıklık, kesinlik, belirginlik, akla uygunluk, derinlik, yoğunluk, mantıklılık, anlamlılık ve dürüstlüktür (Şenşekerci \& Bilgin, 2008: 34-35). Açıklık; öğrencilerin

\footnotetext{
4 Cebrail: Ya Muhammed! Bana İslam'ın ne olduğunu söyle? Hz. Peygamber: İslam; Allah'tan başka ilah olmadığına, Muhammed'in de Allah'ın Resulü olduğuna şehadet etmen, namazı dosdoğru kılman, zekâtı vermen, Ramazan orucunu tutman ve gücün yeterse Beyt'i hac etmendir. Cebrail: Bana imandan haber ver! Hz. Peygamber: Allah'a, Allah'ın meleklerine kitaplarına, peygamberlerine ve ahiret gününe inanman, bir de kadere, hayrına şerrine inanmandır. Cebrail: Doğru söyledin. Bana ihsandan haber ver! Hz. Peygamber: Allah'a O'nu görüyormuşsun gibi ibadet etmendir. Çünkü her ne kadar sen onu görmüyorsan da o seni muhakkak görür. Cebrail: Bana kıyametten haber ver! Hz. Peygamber: Bu meselede kendisine sorulan, sorandan daha çok bilgi sahibi değildir. Cebrail: O hâlde
}

açık ve açık olmayan ifadeler arasındaki ayrımı yapma becerileri kazanmaları için öğrencilere açık olmayan ifadeler verilerek, ifadenin içerebileceği olası anlamları bulma işlemini ifade eder. Kesinlik, öğrencilerin her açık ifadenin kesin olmayabileceğini keşfetmelerini ifade eder. Bunun için öğrencilere açık olmasına karşın kesin olmayan olgusal bildirgeler verilerek, bildirgenin içeriğini araştırmaları ve elde edilen bulguları sözlü ya da yazılı olarak ifade etmeleri istenir. Belirginlik, öğrencilerin belirli bir probleme yönelik belirgin bir bilgi birikimi olmaksızın problem çözmenin olanaksız olduğunu sağlamak için uygulanır. Akla uygunluk, öğrencilerden önce belirli bir koşul, sorun ya da tartışmalı durumu tanımlamaları; ardından açık, kesin ve belirgin olmasına karşın koşullara, soruna ya da tartışmalı duruma uygun olmayan bir durumu bulmaları istenir. Derinlik, öğrencilerin açık, kesin, belirgin, koşullara uygun fakat yüzeysel ifade içeren bir metin üzerinde çalışmaları ve bu metinde yer alan temel problemi ifade etmeleri sağlanır. Ardından, temel problemi nasıl aktardığının ve yaklaşımın neden yüzeysel olduğunun açıklanması ve problemin başka nasıl ifade edilebileceğinin sözlü ya da yazılı olarak tanımlanması istenir. Yoğunluk, öğrencilerin farklı argümanlara göre farklı yargılar geliştirilebilen bir ifade üzerinde çalışmaları sağlanır. Ardından, her bir yargı için ayrıntılara girilmesi ve kişisel görüşlerin bir kenara konularak her bir yanıtın formülleştirilmesi istenir. Daha sonra yargılardan her birinin bu yargıyı benimseyen birinin gözüyle sunulması sağlanır. Mantıklılık, öğrencilerin mantıksız bir düşünce içeren bir metin üzerinde çalışmaları sağlanır. Ardından, düşüncenin dayandığı konunun, mantıksız olduğuna inanılan düşüncenin neden öyle olduğunun ve bu düşüncenin temel bulgularının neler olduğunun açıklanması istenir. Anlamlılık, öğrencilerin öncelikle alışılmış etkinliklere nazaran anlamlı etkinliklere ne kadar zaman harcadıklarını düşünmeleri sağlanması işlemidir. Dürüstlük; öğrencilerden evrensel entelektüel normlar konusunda geliştirmiş oldukları varsayımları gözden geçirmeleri ve bu varsayımların duruma uygun olup olmadıklarına karar vermeleri istenir. Ardından, duruma uymayan varsayımların her biri için, bağlama uygun yeni varsayımlar geliştirmeleri sağlanır (Paul ve Elder, 2020; Şenşekerci \& Bilgin, “2008: 34-35; Kılıç, 2019: 438-439).

Tartışma: Demokratik tutum, sosyalleşme ve birliktelik ruhu kazandırmanın yanında öğrencilerin eleştirel düşünme ve öz eleştiri yapma becerilerinin gelişiminde önemli bir yöntemdir. Tartışma yöntemine dair Kur'an'da örnek bulmak mümkündür (Ra'd,13/16; A'raf, 7/106; Enbiya, 21/59-67; En'am, 6/108). Dahası İslam tarihinde de eğitim öğretimin en önemli yöntemlerinden biri olmuştur (Makdisi, 2015: 170) $)^{5}$ Bu yöntem Müslümanların Müslüman olmayan diğer halklara karşı hoşgörü edinmelerine katkı sağlamıştır (Buğda, 2019: 413). Ayrıca, Kur'an tartışma usulüne dair örneklere de yer vermiştir. "Sen (kötülüğü) en güzel olan

\footnotetext{
bana alâmetlerinden haber ver. Hz. Peygamber: Câriyenin kendi efendisini doğurması ve yalın ayak, çıplak, yoksul koyun çobanlarının bina yapmakta birbirleriyle yarış ettiklerini görmendir

${ }^{5}$ Makdisi, İbni Akil'in kendi fikıh kitabında kullandığı yöntemi şöyle izah ettiğini belirtir: Bu eserimde şöyle bir metot izledim: Mantıki bir sırayla önce kendi görüşlerimi (mezahib) , ardından delilleri (hucec), sonra itirazları (es'ile), ardından itirazlara verilen cevapları (ecvibe) sonra (karșı tezi benimseyenlere ait) sözde delilleri (şübeh), ardından bu (yanlış delilleri çürütmek için verilen) cevapları (ecvibe) sundum. Amacım yeni başlayanlara tartışma metodunu öğretmektir.
} 
davranışla sav; o zaman bir de göreceksin ki seninle aranızda düşmanlık bulunan kimse kesinlikle sıcak bir dost oluvermiş!” (Fussilet, 41/35). 'Rabbinin yoluna hikmetle ve güzel öğütle davet et; onlarla en güzel yöntemle tartış. Kuşkusuz Rabbin, yolundan sapanların kim olduğunu en iyi bilendir; O, doğru yolda bulunanları da çok iyi bilir.' (Nahl,16/125). De ki (Habibim) işte bu benim yolumdur. Ben insanları Allah'a (körü körüne değil) bir basiret üzere davet ediyorum. Ben de bana tabi olanlar da (böyleyiz)' (Yusuf, 12/108).

Ayetlerde de görüldüğü gibi tartışma tekniğini uygularken güzel bir üslup ve akli dayanaklarla temellendirmeye riayet etmek esastır. Günümüz din eğitiminde tartışma yöntemi; çember, panel, zit panel, münazara, kartopu, akvaryum, sempozyum, forum, açık oturum, hızlı tur gibi pek çok şekilde uygulanabilir. Önemli olan öğrencilerin kendi öğrenmelerinin sorumluklarını almaları ve olası eksikliklerini görmelerinin sağlanmasıdır.

\section{Sonuç}

Eleştirel düşünme, hakikati anlamak için aklı işlevselleştirmek ve doğruyu yanlıştan ayırt etmek amacıyla kişinin kendi düşünce sistemindeki yapıları ustaca yönetmesi şeklinde tanımlanabilir. Küreselleşen dünyada bilgi yığınları arasında doğruyu bulmak, dini kendi siyasi emelleri için kullanmak isteyenlere karşı uyanık olmak, farklılıklara karşı tahammül geliştirmek, taklitten ve taassuptan uzak dini bir anlayış geliştirmek için eleştirel düşünme becerisi edinmek şarttır. Eleştirel düşünme becerisini edinmek beraberinde öz eleştiri yapmayı da gerektirir.

Öz eleştiri, eleştirel düşünmeye bağlı olarak kişinin kendini adilce sorgulaması anlamına gelir. Bu sorgulama esnasında kişinin kendisini kıyaslayacağı ölçüt Kur'an ve Sünnet merkezli olmalıdır. Öz eleştiri neticesinde gerekirse tövbe mekanizması işletilmelidir. Bununla birlikte eleştiride olduğu gibi öz eleştiride de İslami usul takip edilmelidir. Aksi durumda batıda olduğu gibi öz eleştiri, öz suçlamaya dönüşebilir.

Kur'an ve sünnet insana bahşedilen aklın kullanılması noktasında gerek kevni ayetlerden gerekse kitabi ayetlerden dersler çıkarılarak hareket edilmesi gerektiğini vazeder. Din eğitimi Kur'an'ın bu yaklaşımını ve eğitim bilimlerindeki verileri dikkate alarak eleştirel düşünme ve öz eleştiri becerilerini muhatabına kazandırmak için yeni yol ve yöntemler geliştirmek zorundadır. Çünkü şuan toplumda asıl sorun eleştirme değil, öz eleştirme yetersizliğidir. Öz eleştirme becerisi aynı zamanda tahammül anlayışının kazanilmasinda temel unsurdur.

Eleştirel düşünme ve öz eleştiri becerilerinin elde edilmesinde, öğretmen yetiştirmeden farklılıklara tahammül gösteren uygun bir sınıf kültürünün/ ortamının oluşturulmasına kadar bütün unsurlar ve safhalar önemlidir. Dil ve düşünce arasındaki irtibat dikkate alınarak din dilinin hem zenginleştirilmesi hem de kullanım usulü noktasında hassas davranılmalıdır. Ayıca öğrenme ortamında öğrencilerin akıllarını işlevselleştirecek aktiviteleri öncelemek esas olmalıdır. Bunun için altı şapkalı düşünme tekniği, beyin firtınası, sokratik tartışma, entelektüel normlar etkinliği, tartışma gibi yöntem/tekniklere yer verilebilir.

\section{Kaynakça}

Aktaş, H. (2020). Din Kültürü ve Ahlak Bilgisi Öğretmenlerinin Empati Düzeyleri İle Öğretmen Özyeterlik Düzeyleri Arasındaki İlişki. Akademik Sosyal Araştırmalar Dergisi, 8(109), 47-64.

Akto, A. (2019). Eleştirel Düşüncenin İnşasında Temel Bir Dinamik Olarak Kur'an. İslam Düşüncesinde Eleştiri Kültürü ve Tahammül Ahlakı. ed. Mahsum Aytepe \& Teceli Karasu. II/579-601. İstanbul: Ensar Yayınları.

Ali, M. M. (2014). Eleştirel Düşünme ve İslami Yöntem. çev. Hülya Çınar. Türk Kültür ve Sanat Araştırmalar Dergisi, 3(2),156-172.

Arca, A. (2019). Kerramiyye'nin Antropomorfist Allah Tasavvurna Fahrettin Razi'nin Yönelttiği Eleştiriler. Islam Düşüncesinde Eleştiri Kültürü ve Tahammül Ahlakl. ed. Mahsum Aytepe \& Teceli Karasu. II/245-262. İstanbul: Ensar Yayınları.

Aydın, Y. (2019). Ortadoğu'da Toplumsal Barışın Sağlanmasında Yüksek Din Öğretimi Kurumlarının Rolü: Ürdün Örneği. İslam Düşüncesinde Eleştiri Kültürü ve Tahammül Ahlakı. ed. Mahsum Aytepe \& Teceli Karasu. II/413-419. İstanbul: Ensar Yayınlar1.

Batar, Y. (2019). Kur'an'da Eleştirel Düşünme EğitimiKavramsal Bir Analiz. Islam Düşüncesinde Eleştiri Kültürü ve Tahammül Ahlakı. ed. Mahsum Aytepe \& Teceli Karasu. I/55-73. İstanbul: Ensar Yayınları.

Bilgin, A. (2019). Anlam Değişmeleri Bağlamında "Eleştiri" Kavramının Eleştirisi. İslam Düşüncesinde Eleştiri Kültürü ve Tahammül Ahlak1. ed. Mahsum Aytepe \& Teceli Karasu. I/44-53. İstanbul: Ensar Yayınları.

Buğda, S. (2019). İslam Hukuk Düşüncesinde Tahammül ve Hoşgörü Bağlamında Zimmilerin Dini Yaşam Hakları. Íslam Düşüncesinde Eleştiri Kültürü ve Tahammül Ahlakl. ed. Mahsum Aytepe \& Teceli Karasu. III/403414. İstanbul: Ensar Yayınları.

Cox, Brian J. vd. (2007). Self-Criticism, Maladaptive Perfectionism, And Depression Symptoms İ A Community Sample: A Longitudinal Test Of The Mediating Effects Of Person-Dependent Stressful Life Events. Journal of Cognitive Psychotherapy: An International Quarterly, 23(4), 336-349.

Çorapçıgil, A. (2014). Öz Değerlendirme Destekli Fizik Laboratuvar Uygulamalarının Üniversite Öğrencilerinin Eleştirel Düşünme Eğilimlerine Etkisi. Yüksek Lisans Tezi. Sakarya: Sakarya Eğitim Bilimleri Enstitüsü.

Doğan, Tayfun vd. (2013). Öz-Eleştiri ve Mutluluk. Kastamonu Eğitim Dergisi, 21(1), 391-400.

Deniz, M. Engin vd. (2012). Öz-Anlayış, Yaşam Doyumu, Negatif ve Pozitif Duygu: Türk ve Diğer Ülke Üniversite Öğrencileri Arasında Bir Karşılaştırma. Mehmet Akif Ersoy Üniversitesi Eğitim Fakültesi Dergisi, 12(23), $428-446$.

Demir, M. (2010). Kur'an'da Tevazu Kavramı. Yüksek Lisans Tezi. Ankara: Ankara Sosyal Bilimler Enstitüsü.

Elmas, H. (2019). Kur'an ve Hadislerde Hz. Peygamber'e Yöneltilen Eleştiriler ve Hz. Peygamberin Tavrı. İslam 
Düşüncesinde Eleștiri Kültürü ve Tahammül Ahlakı. ed. Mahsum Aytepe \& Teceli Karasu. I/159-169. İstanbul: Ensar Yayınları.

Eğmir, E. (2019). Öğretmen Eğitiminde Yansıtıcı Düşünme Uygulamalarına İlişkin Türkiye'de Yapılmış Çalışmaların Analizi. Bolu Abant İzet Baysal Üniversitesi Eğitim Fakültesi Dergisi, 19(1), 194-212.

Ercüment, A. (2019). Dini Çeşitlilik Bağlamında Müslüman Toplumlarda Şiddet, Eleştiri ve Birlikte Yaşam Kültürü. Íslam Düşüncesinde Eleştiri Kültürü ve Tahammül Ahlakı. ed. Mahsum Aytepe \& Teceli Karasu. I/505-520. İstanbul: Ensar Yayınları.

Ev, H. (2014). Eleştirel Düşünme ve Din Kültürü ve Ahlak Bilgisi Dersi. İzmir: Tıbyan Yayıncılık.

Gülaçar, İ. (2019). Gazzali'de Eleştirel Yöntem- el-Munkız Mine'd Delal Örneği. İslam Düşüncesinde Eleştiri Kültürü ve Tahammül Ahlakl. ed. Mahsum Aytepe \& Teceli Karasu. III/503-511. İstanbul: Ensar Yayınları.

İnan Kılıç, A. (2019). Eleştirel Düşüncenin Geliştirilmesinde Din Eğitiminin Rolü. İslam Düşüncesinde Eleştiri Kültürü ve Tahammül Ahlak1. ed. Mahsum Aytepe \& Teceli Karasu. I/425-443. İstanbul: Ensar Yayınları.

Karasu, T. (2020). Din Eğitiminde İşlevsel Akıl. Ankara: Araştırma Yayınları.

Karasu, T. (2019). Din Eğitiminden Eleştirel Düşünme Eleştiri. Íslam Düşüncesinde Eleştiri Kültürü ve Tahammül Ahlakı. ed. Mahsum Aytepe \& Teceli Karasu. I/43-456. İstanbul: Ensar Yayınları.

Koca, B. (2019). Müslüman Ailede Tahammül Eğitimi. Íslam Düşüncesinde Eleștiri Kültürü ve Tahammül Ahlakl. ed. Mahsum Aytepe \& Teceli Karasu. II/125-148. İstanbul: Ensar Yayınları.

Kökdemir, D. (2020). Eleştirel Düşünme: Kapsamı ve Eğitimi. (Erişim 5 Aralık 2020). http://elyadal.org/docs/kokdemir_ed.pdf.

Makdisi, G. (2015). Ortaçă̆'da Yüksek Öğretim. terc. Ali Hakan Çavuşoğlu\&Tuncay Başoğlu. İstanbul: Klasik Yayınları.
Nosich, G. M. (2018). Disiplinlerarası Eleştirel Düşünme Rehberi. çev. Birsel Aybek. Ankara: Anı Yayıncılık.

Paul, R \& Elder, L. (2020). The Miniature Guide to Critical Thinking: Concepts \& Tools, 1-22, (Erişim 4 Aralık 2020).

https://www.criticalthinking.org/files/Concepts_Tools.p df;

Paul, R.\& Elder, L. (2020). Minik Eleştirel Düşünme Kılavuzu Minik Eleştirel Düşünme Kılavuzu Kavramlar ve Araçlar. çev. Merih Bektaş Fidan. (Erişim 2 Aralık 2020. https://www.criticalthinking.org/files/Turkish_CT_Conc epts_Tools.pdf

Seferoğlu S. \& Akbıyık, C. (2006). Eleştirel Düşünme ve Öğretimi. Hacettepe Üniversitesi Ĕ̆itim Fakültesi Dergisi 30(30), 193-200.

Şahin, M. (2018). Eğitimde Eleştirel Düşünme. Eğitim ve Öğretim Araştırmaları Dergisi, 7(3) 40-49.

Şenşekerci E. \& Bilgin, A. (2008). Eleştirel Düşünme ve Öğretimi. Uludă̆ Üniversitesi Fen-edebiyat Fakültesi Sosyal Bilimler Dergisi, 14(1) 15-43.

Topaloğlu, B. (2020). “Tövbe”, Türkiye Diyanet Vakfi İslâm Ansiklopedisi. (Erişim 3 Aralık 2020). https://islamansiklopedisi.org.tr/tovbe\#1

Turşak, M. (2017). Dinî Kişiliğin Oluşmasında Özeleştirinin Etkisi. A Ăr İslâmi İlimler Dergisi 1(1), 127-140.

Türk Dil Kurumu. Erişim 1 Aralık 2020. https://sozluk.gov.tr/

Yıldız, R. (2019). Eleştiri Kültürü ve Tahammül Ahlakına F1khı Yaklaşım. Íslam Düşüncesinde Eleştiri Kültürü ve Tahammül Ahlakı. ed. Mahsum Aytepe \& Teceli Karasu. I/387-401. İstanbul: Ensar Yayınları. 


\section{Extended Abstract}

Life is tried to be understood by using the ability to think. Thanks to the ability to think, questions such as who it is, where it is experienced, what are the similarities and differences with other beings are answered. However, both internal and external factors such as environmental conditions, indolence, negligence and devil's deceptions can prevent the individual from seeking the truth. These factors, which prevent the use of the mind, block the truth and prevent the person from reaching it and living a correct life. At this point, critical thinking and self-criticism developed based on it are two important elements that can help a person find the truth in accordance with his nature.

Critical thinking can be defined as the skillful management of structures in one's own thinking system in order to functionalize the mind and to distinguish right from wrong. In the globalizing world, it is essential to acquire critical thinking and self-criticism skills in order to find the truth among the masses of knowledge, to be alert to those who want to use religion for their own political purposes, to develop tolerance against differences, and to develop a religious understanding that is far from imitation and fanaticism.

Critical thinking is a way of thinking that contributes to an individual's better understanding by reflecting on his own feelings, thoughts and behaviors and questioning himself. In this way of thinking, cognitive errors are recognized, inconsistent judgments are eliminated, analysis can be made by looking at the subject from different dimensions, and ideas are analyzed on a realistic basis. Thanks to critical thinking, the person grasps the reason for existence, develops a solid self-imagination and can live by evaluating the world more accurately. On the other hand, individuals who have not developed critical thinking skills live in a way that is trapped in static, dogmatic and egocentric patterns.

Critical thinking is the basis for both criticism and selfcriticism. While criticism is conceptually based on the analysis of the other person, society and thought, selfcriticism can be expressed as the process of questioning one's own feelings, thoughts and behaviors. In this sense, selfcriticism is an internal criticism. In other words, it is an objective evaluation of oneself, a principled, open and honest attitude towards their mistakes. It is the ability to analyze them without clearing the soul, without covering up their flaws, without connecting them to others or the nature of things. Self-criticism is the self-accounting, reasonable, consistent and realistic questioning of a person, group or society. Self-criticism, which is extremely important for the development of individuals and societies to search and find the deficiencies, to do better to improve and supply, to make the work done, to re-evaluate, to review, acts as a control.

Self-criticism, which is internal accounting in a sense, is the ability to see and regulate the self-centered structure of one's thinking style. It is the realization of practices contrary to the purpose of creating by questioning his soul, regretting it and returning from it. A believer's realization of his own weaknesses and faults brings him to his Lord with repentance and forgiveness. Thus, a believer can correct and fulfill his personality by taking into account the principles set forth by his Lord. Allah ".. who purifies his soul has attained salvation." (Şems, 91/9), in a sense, encourages self- criticism as self-control. When making self-criticism, it is important for a person to determine the value criteria based on the Quran and Sunnah. Otherwise, the person may deviate from self-criticism and turn to self-blame. In this case, the person moves away from his nature and his own reality. Hopelessness, guilt, insecurity and unhappiness become the most intense emotions that people experience. Therefore, a person should evaluate himself / herself according to objective religious principles and values.

Self-criticism also plays a major role in acquiring the correct self-perception. With self-criticism, it becomes only possible for the individual to bring the current self-perception and the ideal self-perception closer together. This is because the person can close the distance between the place where he is located and the place he wants to reach. Thus, a person can find a Qur'an-centered solution a way to get rid of his selfish inclinations.

Learning critical thinking and self-criticism skills through religion lesson contributes to their ability to establish the relationship between reason and revelation correctly. These skills cognitively enable the person to understand members of different religions in our globalizing world. It removes them from accepting the text without discussing it, from sect, sect, community fanaticism, and unconscious imitations.

The most important issue in developing students' critical thinking and self-criticism skills is the presence of a teacher who can use strategies, methods and techniques that add functionality to the mind. In addition, the teacher has an official responsibility for the students to gain critical thinking skills. In the curriculum; "He / she applies a variety of teaching strategies to encourage the development of critical thinking, problem solving, and performance." The statement makes Religion teachers responsible. When the teacher does not do his / her duty, the lessons take the form of lessons that are not open to questioning and where dogmatic information is given.

In the acquisition of critical thinking and self-criticism skills, all elements and stages from training teachers to the creation of an appropriate classroom culture / environment that tolerates differences are important. In a culture that embraces obedience without thinking, it is very difficult for students to gain critical thinking and self-criticism skills. In addition, attention should be paid to both the enrichment of the language of religion and the way it is used. In this sense, such as thinking hats technique, brainstorming, socratic discussion, intellectual norms activity, discussion can be used in lessons. 